\title{
The performance and genetic variation of first and second generation tropical alfalfa (Medicago sativa)
}

\author{
BAMBANG SUWIGNYO^, LUKMANA ARIFIN, NAFIATUL UMAMI, MUHLISIN, \\ BAMBANG SUHARTANTO \\ Faculty of Animal Science, Universitas Gadjah Mada. J1. Fauna No. 3, Bulaksumur, Sleman 55281, Yogyakarta, Indonesia. \\ Tel.: +62-274-513363, Fax.: +62-274-521578, `email: bsuwignyo@ugm.ac.id \\ Manuscript received: 4 March 2021. Revision accepted: 22 May 2021
}

\begin{abstract}
Suwignyo B, Arifin L, Umami N, Muhlisin, Suhartanto B. 2021. The performance and genetic variation of first and second generation tropical alfalfa (Medicago sativa). Biodiversitas 22: 3265-3270. This study aimed to compare the growth performance, nutrient content, seed viability, and genetic variation of first- and second-generation alfalfa (Medicago sativa L.). First and secondgeneration alfalfa seeds were obtained from the Forage and Pasture Science Laboratory, Department of Animal Nutrition and Feed Science, Faculty of Animal Science, Universitas Gadjah Mada (UGM), Yogyakarta, Indonesia. First generation alfalfa (F1) seeds were obtained from cross breeding of two different parental alfalfa varieties, namely, Canadian and local. The second-generation (F2) seeds were obtained from plants of the first-generation alfalfa (F1). A randomized design experiment was conducted using the two types of alfalfa (first- and second generation). Alfalfa from Canada as female parent was used as the baseline in the genetic masker test. Seeds were planted in a polybag, watered twice a day, and received 12 hours of daylight and 4 hours of artificial light. Plants were then harvested 8 weeks after planting by cutting the plant canopy. Genetic variation was examined using the Inter Simple Sequence Repeat (ISSR) method followed by descriptive analysis. Germination, plant height, dry matter content, organic matter, and crude protein were assessed as variables using a Student's T-test. Our results showed that germination, plant height, leaf color, and nutrient content (dry matter, organic matter, and crude protein) of the first- and second-generation alfalfa plants were not significantly different. However, the second-generation alfalfa demonstrated better seed viability than the first generation plants, then it can be categorized as a new genotype (tropical alfalfa) based on genetic variation analysis.
\end{abstract}

Keywords: ISSR, lucerne, nutrition, variety, viability

\section{INTRODUCTION}

Forage feed plays an important role in supporting the productivity of ruminants, which can be a problem often faced by farmers in terms of availability quality and costs during the growing and production periods. It is well accepted that feed comprises up to $70 \%$ of total production costs in livestock rearing. One effort to increase the availability of quality forage feed is to introduce legume plants. These plants, such as alfalfa (Medicago sativa $\mathrm{L}$ ), have high protein content as well as good nutritional and digestive value. Alfalfa has the potential to be used as feed due to its high protein, vitamin, and mineral content. Although alfalfa is not a tropical legume, it has the potential to be developed in Indonesia for plant seed as well as fresh forage for animals (Suwignyo et al. 2016). However, there are some constraints for farming alfalfa in tropical areas such as Indonesia. Phosphorus and potassium remain in rock form and have not been broken down for sufficient absorption by alfalfa plant roots. Importantly, it has been shown that the length of exposure to these nutrients as well as the addition of dolomite can affect the ability of alfalfa plants to reach the generative phase (Suwignyo et al. 2017). Information on the characterization of genetic resources is required for the development of new cultivars. For breeding purposes, the distribution of Lucerne in various regions and climates is a good indication in terms of plant breeding purposes. This information is useful in determining options for the Luzern breeding method towards new cultivar discovery (Al-Faifi et al. 2013).

This study determined productivity differences, generative potential, and genetic variation of Canadian alfalfa crossed with local variety and their respective first and second generations. Genetic variation among plant varieties was also examined using the inter-simple sequence repeat (ISSR) molecular marker method.

\section{MATERIALS AND METHODS}

\section{Study area}

First and second-generation alfalfa seeds harvested from the Forage and Pasture Science Laboratory, Department of Animal Nutrition and Feed Science, Faculty of Animal Science, Universitas Gadjah Mada (UGM), Yogyakarta, Indonesia. First and second generation was obtained by mass selection, from 85 plants (in 6 groups) 6 plants (either F1 or F2) with the best performance were taken as seed samples. First generation alfalfa (F1) was resulted from cross breeding of two different parental alfalfa varieties, from Canada and another one (unknown varieties). Two types of alfalfa seeds (first- and second generation) were used in a randomized design experiment. 
Alfalfa from Canada as female parent was used as the baseline in the genetic masker test.

\section{Procedures}

The implementation of the study

The growing media consisted of a soil mixture with 150 g polybag ${ }^{-1}$ coco peat fertilizer, $90 \mathrm{~g} \mathrm{polybag}^{-1}$ dolomite, and $1.5 \mathrm{~g}$ polybag $^{-1}$ SP-36 fertilizer. The polybags were placed in a $30 \times 50 \mathrm{~cm}$ spacing area. The soil-fertilizer mixture was watered for four consecutive days prior to use. There were 42 plants used in this study ( 21 plants per generation). Two seeds were planted in each polybag. Watering was performed daily at $07.00 \mathrm{~h}$ and $16.30 \mathrm{~h}$. Plants received 16 hours of light, which included 12 hours of natural sunlight and 4 hours of artificial light (1800 to $2200 \mathrm{~h}$ ). Harvesting alfalfa was done by cutting the whole plant about $5 \mathrm{~cm}$ from the soil surface. Plants were harvested at about 8 weeks after planting (WAP) when the plants were approaching flowering. Plant samples were taken on a weekly basis to determine plant height, dry matter, organic matter and crude protein contents. Counting of seedlings was conducted on a weekly basis to determine the germination rate. Leaf color was measured at 2, 4, 6, and 8 weeks of age using a color chart.

The ISSR method was conducted to examine the genetic variation using alfalfa leaf samples, whereby leaf number $5^{\text {th }}$ from the top of each plant was used. DNA was extracted from the samples and amplified by PCR using the primers listed in Table 1 in a $25 \mathrm{uL}$ reaction volume on a Thermo Cycler PCR machine from BioRad. Amplified DNA was visualized using $2 \%(\mathrm{~m} / \mathrm{v})$ agarose gel electrophoresis.

\section{Data analysis}

Additional parameters were also assessed, including germination rate percentage, plant height, forage color, dry matter content, organic matter, and crude protein. Research variables were compared using a Student's T-test in the Statistical Package for the Social Sciences (SPSS) program (version 24) according to a previously described method (Márquez 2007). In this study the T-test was used for comparison of the means because there were only 2 test groups, namely first and second generation alfalfa. Genetic variation was analyzed descriptively based on the genetic distance and dendrogram from the PCR results.

Table 1. Primary sequence of the 7 ISSR primer sequences

\begin{tabular}{lll}
\hline \multicolumn{2}{c}{ Primer } & \multicolumn{1}{c}{ Sequence } \\
\hline \multirow{2}{*}{ ISSR } & UBC809 & 5' AGAGAGAGAGAGAGAGG 3', \\
(Tiwari & UBC823 & 5' TCTCTCTCTCTCTCTCC 3' \\
et al. & UBC873 & 5' GACAGACAGACAGACA 3' \\
2016) & UBC817 & 5' CACACACACACACACAA 3' \\
& UBC807 & 5' AGAGAGAGAGAGAGAGT 3', \\
& UBC861 & 5' ACCACCACCACCACCACC 3' \\
& NG3 01 & 5' ACAACAACAACAACASS3' \\
\hline
\end{tabular}

\section{RESULTS AND DISCUSSION}

\section{Germination}

Germination percentages of first- and secondgeneration alfalfa plants are shown in Table 2.

\section{Alfalfa plant height}

There was no significant difference in plant height between generations ( $P>0.05$; Table 3 ) on alfalfa plant height at each age of observation. The average growth rate (cm/day) of the first- and second-generation alfalfa is shown in Figure 1.

The growth pattern of both alfalfa generations was similar and shaped like protractor, with fast growth in the first to third week then slowed down after the fourth week (Figure 1). The plant growth acceleration rate was determined by the difference between the n-week plant height and n-1 divided by the number of days in one week.

\section{Nutrient content of alfalfa plants}

There was no significant difference in the average content of DM, OM, and CP between the two generations (P > 0.05; Table 4). Parameter for leaf color was assessed every two weeks in alfalfa plants from 2 WAP to 8 WAP (Table 5). There was no significant difference in leave greenness between the two generations at any observation time point $(\mathrm{P}>0.05)$. The leaf color of both alfalfa generation (measured by leaf color chart) can be seen in Table 5.

\section{Viability test}

Seed viability is the viability of seeds that can be demonstrated in a variety of physiological and biochemical conditions. Technically, the viability test was done by placing a number of seeds on moisture cotton for several days. Both of the seed was harvested and dried prior to test (without storage it). Our results showed that secondgeneration alfalfa had greater potential to be used as seed than first-generation plants, as shown in Table 6.

\section{Genetic variation test}

Nanodrop spectrophotometry results showed that DNA concentrations from parental as well as first- and second generation alfalfa plants can be seen in Table 7. The seven ISSR primers successfully amplified the three analyzed samples. As shown in Figure 2, the three samples had marked differences with regard to the amplification band pattern.

Conversion of these data into a binary scoring matrix dendrogram is illustrated in Figure 3. On the other hand, a dendrogram binary matrix conversion result between samples is shown in Table 8 . The matrix similarity value among parental, first and second generation alfalfa is shown in Table 8. The comparison of DNA gel electrophoresis among parental, first and second-generation alfalfa is shown in Figure 2. The dendrogram containing parental, first and second-generation alfalfa can be seen in Figure 3. 
Table 2. The germination rate (\%) during the first week of planting of first- and second-generation alfalfa plants

\begin{tabular}{ccc}
\hline \multirow{2}{*}{$\begin{array}{c}\text { Age } \\
\text { (days after } \\
\text { planting) }\end{array}$} & \multicolumn{2}{c}{ Germination percentage } \\
\cline { 2 - 3 } & First-generation & Second-generation \\
\hline 1 & $0 \%$ & $0 \%$ \\
2 & $17 \%$ & $33 \%$ \\
3 & $25 \%$ & $42 \%$ \\
4 & $50 \%$ & $42 \%$ \\
5 & $50 \%$ & $50 \%$ \\
6 & $50 \%$ & $50 \%$ \\
7 & $50 \%$ & $50 \%$ \\
\hline
\end{tabular}

Table 3. The average height $(\mathrm{cm})$ during the first 8 days of growth of F1 and F2 alfalfa plants

\begin{tabular}{ccc}
\hline \multirow{2}{*}{$\begin{array}{c}\text { Age } \\
\text { (weeks after } \\
\text { planting) }\end{array}$} & \multicolumn{2}{c}{ Plant height $(\mathbf{c m})$} \\
\cline { 2 - 3 } & First-generation & Second-generation \\
\hline 1 & $2.72 \pm 0.57$ & $2.67 \pm 0.74$ \\
2 & $4.70 \pm 1.66$ & $3.50 \pm 0.73$ \\
3 & $10.42 \pm 2.79$ & $10.46 \pm 2.71$ \\
4 & $20.10 \pm 5.49$ & $18.97 \pm 5.54$ \\
5 & $30.11 \pm 7.51$ & $28.08 \pm 8.06$ \\
6 & $38.51 \pm 9.67$ & $36.98 \pm 9.71$ \\
7 & $45.26 \pm 11.59$ & $43.51 \pm 13.29$ \\
8 & $47.44 \pm 11.86$ & $46.38 \pm 13.77$ \\
\hline
\end{tabular}

Table 4. Nutrient content of alfalfa plants

\begin{tabular}{lcc}
\hline Nutrient content & First-generation & Second-generation \\
\hline Dry matter (\%) & $21.37 \pm 0.57$ & $21.6 \pm 0.13$ \\
Organic matter (\% DM) & $88.82 \pm 1.03$ & $88.99 \pm 0.81$ \\
Crude protein (\% DM) & $16.70 \pm 0.83$ & $16.30 \pm 0.75$ \\
\hline
\end{tabular}

Table 5. Leaf greenness of in the F1 and F2 alfalfa plants over 8 weeks growth

\begin{tabular}{ccc}
\hline \multirow{2}{*}{$\begin{array}{c}\text { Plant age } \\
\text { (WAP) }\end{array}$} & \multicolumn{2}{c}{ Average of leaves greenness } \\
\cline { 2 - 3 } & First-generation & Second-generation \\
\hline 2 & $2.00 \pm 0.00$ & $2.13 \pm 0.19$ \\
4 & $2.80 \pm 0.63$ & $2.58 \pm 0.49$ \\
6 & $3.30 \pm 0.75$ & $2.81 \pm 0.58$ \\
8 & $3.82 \pm 0.93$ & $3.81 \pm 0.91$ \\
\hline
\end{tabular}

Table 6. Alfalfa seed viability tests

\begin{tabular}{ccc}
\hline $\begin{array}{c}\text { Age } \\
\text { (days after } \\
\text { planting) }\end{array}$ & \multicolumn{2}{c}{ Viability percentage } \\
\cline { 2 - 3 } & First-generation & Second-generation \\
\hline $1^{\text {ist }}$ & 0 & 0 \\
$2^{\text {nd }}$ & $15 \%$ & $10 \%$ \\
$3^{\text {rd }}$ & $28 \%$ & $45 \%$ \\
$4^{\text {th }}$ & $45 \%$ & $68 \%$ \\
$5^{\text {th }}$ & $68 \%$ & $80 \%$ \\
Final result & $68 \%$ & $80 \%$ \\
\hline
\end{tabular}

Table 7. Purity (units) and concentration (units) of genomic DNA

\begin{tabular}{lcc}
\hline Sample & Concentration & Purity \\
\hline Parental plant & $816.81 \mathrm{ng} \mu \mathrm{L}^{-1}$ & 1.766 \\
First-generation & $545.47 \mathrm{ng} \mu \mathrm{L}^{-1}$ & 1.565 \\
Second-generation & $629.70{\mathrm{ng} \mu \mathrm{L}^{-1}}$ & 1.706 \\
\hline
\end{tabular}

Table 8. Matrix of similarity among samples

\begin{tabular}{cccc}
\hline Sample & $\mathbf{1}$ & $\mathbf{2}$ & $\mathbf{3}$ \\
\hline 1 & 100.000 & & \\
2 & 81.132 & 100.000 & \\
3 & 75.000 & 67.391 & 100.000 \\
\hline
\end{tabular}

Note: 1. Parental alfalfa (female); 2. First-generation alfalfa; 3. Second-generation alfalfa

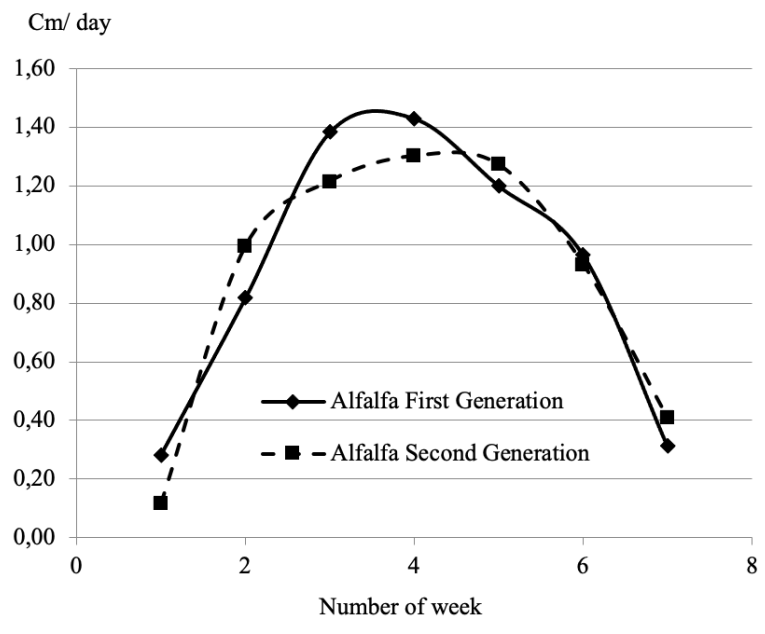

Figure 1. Average growth acceleration rate ( $\mathrm{cm} /$ day) of first- and second-generation alfalfa plants

\section{Discussion}

The germination rates of first- and second-generation alfalfa seeds showed that only $50 \%$ of the seeds germinated. This was probably because the seeds in this study were not previously immersed in water, which could affect germination especially in the first step namely imbibition of water. Ghogdi et al. (2012) stated that there is two phases in the germination process. The first is imbibition, mainly depending on the physical characteristic of the seed and the second is the heterotrophic growth phase between imbibition and emergence. In addition, according to Babakhani et al. (2011) stated that seed germination is usually limited by the intensity of abiotic stress, such as high salinity. Biotic, abiotic, and

environmental stresses such as salinity and alkalinity can stimulate the production of ethylene, which plays a role in inhibiting plant growth (Abeles et al. 2012). 


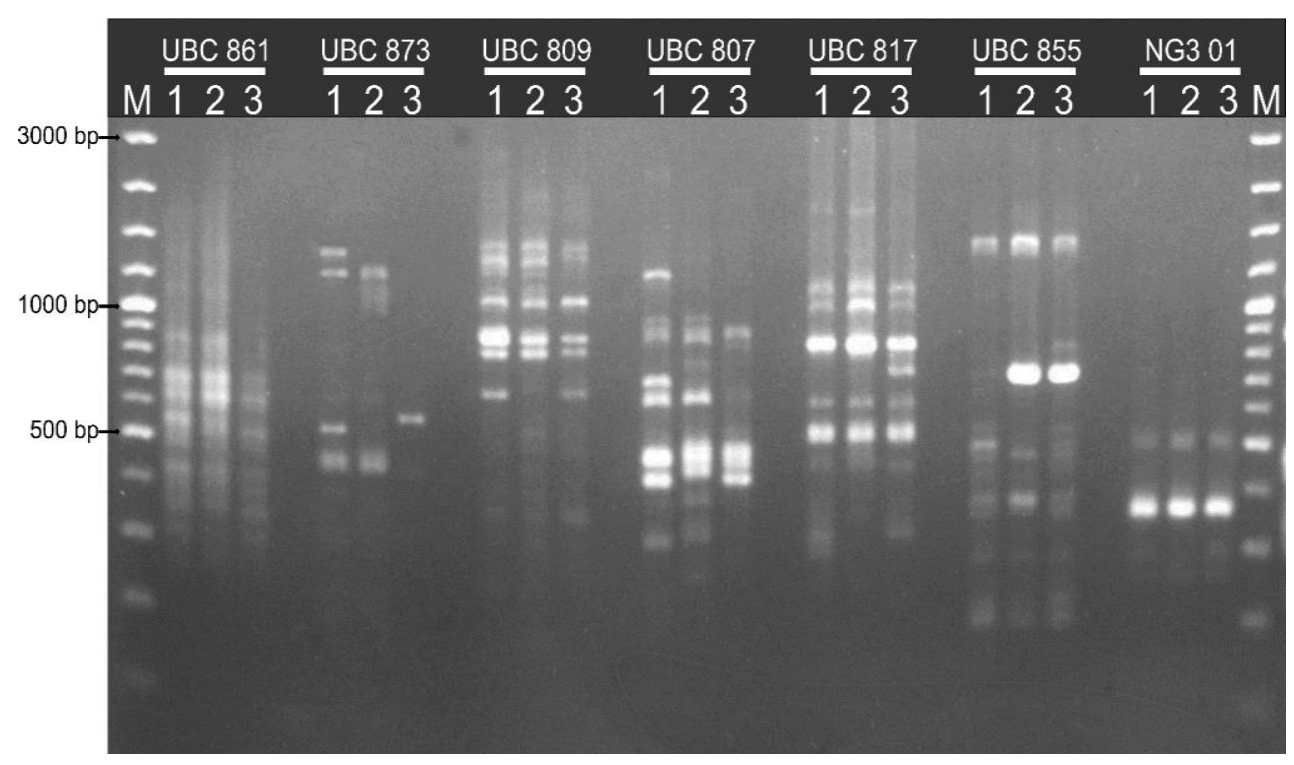

Figure 2. Gel electrophoresis of DNA obtained from parental as well as first- and second-generation alfalfa leaves. M: 100 bp DNA ladder; 1: parental alfalfa (female); 2: first-generation alfalfa; 3 : second-generation alfalfa

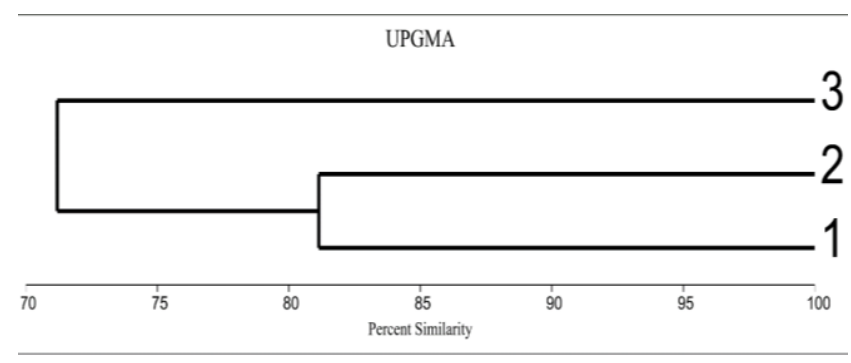

Figure 3. Dendrogram of three samples; 1: parental alfalfa (female); 2: first-generation alfalfa; 3 : second-generation alfalfa

Height of plant is an important indicator to determine plant biomass production (dos Santos et al. 2018). Plant height is also an indicator of performance, which is very likely related to seed production (quantity and quality) (Podolska 2014). Alfalfa plant height increased each week in both generations and was similar to heights reported in a study conducted in Canada $(30-90 \mathrm{~cm})$ (Britannica 2019). The growth rates in the first- and second generations slowed by 6 weeks after cutting and were not significantly different (Tabel 1 and Figure 1). It is known that when plants reach a certain size, they shift energy into forming flower primordial as a result of physiological processes, which are characterized by a decrease in growth activity. Plant height growth rate in this research similar to research done by Stavarache et al. (2015) found that plant height increases during plant development with a tendency to stabilize, starting from the beginning of flowering until the harvest time.

The dry matter and organic matter of alfalfa, either in the first and second generations were not significantly different. This was because alfalfa was cut at the same age, 8 WAP. Purbajanti (2013) stated that plant age affects the dry matter content. The older of plant, the higher of dry matter content. Plant age is considered to have more influence on the dry matter content of alfalfa plants than the duration of lighting. In addition, dry matter is closely related to organic matter. Increase in dry matter production will be followed by increased production of organic matter.

Based on the research of Widiastuti and Latifah (2016), the dry weight is more influenced by varieties, Burangrang (soybean) with high genetic potential which has the highest plant height also has the highest dry weight. Plant dry weight is influenced more by plant genetics than by treatment. According to Bocianowski et al. (2016), quantitative characters are controlled by many genes where the effect of each gene on the appearance of the character (phenotype) is smaller and is additive. These genes together have a bigger influence than the influence of the environment. Such genes are called minor genes. Minor gene action is determined by the form of interaction that occurs in both interactions between alleles at the same locus. Ye et al. (2017), for quantitative characters, interactions between alleles can occur in the form of additive and dominant interactions as well as interactions between alleles at different loci (epistasis).

The Crude Protein (CP) value of this study was within a previous research, ranged 19.53-20.31\% (Suwignyo et al. 2016). According to Fan et al. (2018), alfalfa leaves contain 15 to $22 \%$ of crude protein. High quality alfalfa had $>19 \%$ $\mathrm{CP}$ in general, but particularly at full bloom stage alfalfa forage had to contain a CP>16\% (Kazemi et al. 2012). Factors affecting the variation of crude protein content in alfalfa plants include plant age, growth stage, plant parts, stem-to-leaf ratio, and soil fertility (Purbajanti 2013). Harvest time can also affect alfalfa protein content. Cutting alfalfa at the optimum growth stage can improve both hay yield and quality (Yari et al. 2012). Harvesting at the early flower stage is currently thought to result in high yields and 
nutrient concentrations in alfalfa forage (Kiraz 2011). The crude protein content of alfalfa leaves continuously decreased with delayed harvest maturity (Lamb et al. 2014). However, ecology also plays role in the crude protein content. Differences in CP content can be due to differences in cultivars and ecology (Turan et al. 2017). Previous research finding has indicated that alfalfa crude proteins content are mainly located in chloroplasts, and the transition from vegetative growth to reproductive growth of alfalfa increases nutrient production and lignification, leading to a decrease in the crude protein content (Lamb et al. 2012).

A viability test is conducted to determine the potential of seeds to germinate from a group of seeds. Viability test to observe the ability and potential change of alfalfa seeds (Kwack et al. 2014). Seed viability information is useful for estimating seed requirements in a given area. Seed viability is an indicator estimating the seed yield (Ambrose et al. 2016). Viability value of second generation was higher than first generation of alfala.

Based on the ISSR data, two varieties of alfalfa were observed: the variety consisting of the parent (No. 1) and first-generation (No. 2) alfalfa, and the variety consisting of the second-generation (No. 3) alfalfa. The first-generation alfalfa has closer similarity with parental (differences < $50 \%$ ), compared with second-generation (differences > $50 \%$ ). The phenotypic performance can be seen from the plant's height, stem size and time of appearance of flowers. The F2 plants have similarities in terms of leaf type (trifoliate) and flower shape (bunches) with the F1 and their parents. However, the F2 alfalfa plants have a stem size and plant height intermediate of the two parents. The F2 plants flowered at the age of 21 days from cutting, while the parents took 48 days to flower.

The genetic distance between the parental and firstgeneration alfalfa showed several segments of repeat sequences in mitochondrial DNA that were inherited simultaneously at several gene loci. Several polymorphic genes can be passed on from the female parent to the dominant first offspring. After the first-generation undergo self-pollination, there are several combinations of new variations that can cause the second-generation to be genetically distant from the parental and first-generation plants. One way to determine distinct varieties is by assessing genetic distance. ISSR primers to detect genetic fidelity in regenerating plants (Jung et al. 2021).

ISSR is an effective technology for this purpose because it can show genetic variation and is not influenced by environmental variations. Genetic distance measurements can vary between 0 and $1(100 \%)$, whereby a 0 is obtained if the genetic structure of the two populations is identical and a 1 is achieved if the two populations have a non-identical genetic type (Finkeldey 2005). Importantly, if the similarity between strains is more than $70 \%$, it can be grouped into one species. Finally, if the similarity level is more than $90 \%$, then it can be grouped into the same strain (Cahyarini et al. 2004).

The results showed the comparison of the productivity (nutrient content, height and speed of plant growth, growth capacity) of parent alfalfa versus crossed bred alfalfa. In addition to performance comparisons, there is also genetic comparison, to prove whether the alfalfa is still in one strain or not. The result of genetic analysis (ISSR) proved that the first generation and parent were still one variety, but not with second generation (F2), thus $\mathrm{F} 2$ will be considered as tropical alfalfa.

It can be concluded that the growth performance, nutrient contents and seed viability of first- and secondgeneration alfalfa (Medicago sativa L.) plants were not significantly different. However, the seeds of secondgeneration plants exhibited better growing ability. In addition, based on ISSR analysis, the second-generation alfalfa in this study can be categorized as a new alfalfa strain/variety (tropical alfalfa).

\section{ACKNOWLEDGEMENTS}

The researchers wish to thank Ganies Riza Aristya, Eprilia Aristia Rini and Dean Ali Agus for their support, discussion, and assistance.

\section{REFERENCES}

Abeles FB, Page WM, Mikal ESJ. 2012. Ethylene in Plant Biology. $2^{\text {nd }}$ ed. Academic Press, London.

Al-Faifi SA, Migdadi HM, Al-doss A, Ammar MH, El-Harty EH, Khan MA, Muhammad JM, Alghamdi SS. 2013. Morphological and molecular genetic variability analyses of Saudi lucerne (Medicago sativa L.) landraces. Crop Pasture Sci 64 (2): 137-146. DOI: 10.1071/CP12271

Ambrose A, Lohumi S, Lee HW, Cho BK. 2016. Comparative nondestructive measurement of corn seed viability using Fourier transform near-infrared (FT-NIR) and Raman spectroscopy. Sensors Actuators B: Chem 224: 500-506. DOI: 10.1016/j.snb.2015.10.082

Babakhani B, Khavari-Nejad RA, Fahimi H, Saadatmand S. 2011. Biochemical responses of alfalfa (Medicago sativa L.) cultivars subjected to $\mathrm{NaCl}$ salinity stress. Afr J Biotechnol 10 (55): 1143311441.

Bocianowski J, Górczak K, Nowosad K, Rybiński W, Piesik D. 2016. Path analysis and estimation of additive and epistatic gene effects of barley SSD lines. J Integr Agric 15 (9): 1983-1990. DOI: 10.1016/S2095-3119(15)61243-6

Britannica. 2019. Alfalfa. 2019. www.britannica.com/plant/alfalfa Accessed 2019-09-05.

Cahyarini RD, Yunus A, Purwanto E. 2004. Identification of the genetic diversity of some local varieties of soybean in java based on isozyme analysis. Agrosains 6 (2): 79-83

dos Santos, Cruz CD, Nascimento M, Rosado RDS, Ferreira dPR. 2018. Direct, indirect and simultaneous selection as strategies for alfalfa breeding on forage yield and nutritive value. Pesq Agropec Trop 48 (2): 178-189. DOI: 10.1590/1983-40632018v4851950

Fan W, Ge G, Liu Y, Wang W, Liu L, Jia Y. 2018. Proteomics integrated with metabolomics: Analysis of the internal causes of nutrient changes in alfalfa at different growth stages. BMC Plant Biol 18 (1): 78. DOI: $10.1186 / \mathrm{s} 12870-018-1291-8$

Finkeldey R. 2005. An Introduction to Tropical Forest Genetics. Institute of Forest Genetics and Forest Tree Breeding. Georg August University Gottingen. Gottingen, Germany.

Ghogdi EA, Izadi A, Borzouei A. 2012. Effects of salinity on some physiological traits in wheat (Triticum aestivum L.) cultivars. Indian $\mathrm{J}$ Sci Technol 5 (1): 1901-1906. DOI: 10.17485/ijst/2012/v5i1.23

Jung WS, Chung IM, Kim SH, Chi HY, Yu CY, Ghimire BK. 2021. Direct shoot organogenesis from Lycium chinense Miller leaf explants and assessment of genetic stability using ISSR markers. Agronomy 11 (3): 503. DOI: 10.3390/agronomy11030503

Kazemi M, Abdul MT, Abas AN, Reza V, Mohammad MM. 2012. Potential nutritive value of some forage species used as ruminants 
feeds in Iran Afr J Biotechnol 11 (57): 12110-12117. DOI: 10.5897/AJB12.286

Kiraz AB. 2011. Determination of relative feed value of some legume hays harvested at flowering stage. Asian J Anim Vet Adv 6 (5): 525530. DOI: 10.3923/ajava.2011.525.530

Kwack Y, Kim KK, Hwang H, Chun C. 2014. An ozone micro-bubble technique for seed sterilization in alfalfa sprouts. Hortic Sci Technol 32 (6): $901-905$. DOI: 10.7235 /hort.2014.14129

Lamb JFS, Jung HG, Riday H. 2012. Harvest impacts on alfalfa stem neutral detergent fiber concentration and digestibility and cell wall concentration and composition. Crop Sci 52 (5): 2402-2412. DOI: 10.2135/cropsci2012.01.0027

Lamb JFS, Jung HG, Riday H. 2014. Growth environment, harvest management and germplasm impacts on potential ethanol and crude protein yield in alfalfa. Biomass Bioenerg 63: 114-125. DOI 10.1016/j.biombioe.2014.02.006

Márquez AC. 2007. The Maintenance Management Framework: Models and Methods for Complex Systems Maintenance. Springer Science \& Business Media, New York.

Podolska G. 2014. Plant lodging, effects, and control. Encyclopedia of Agrophysics, Part of the Series Encyclopedia of Earth Sciences Series 2014: 609-610

Purbajanti ED. 2013. Rumput dan Legum sebagai Hijauan Makanan Ternak. Graha Ilmu, Yogyakarta. [Indonesian]

Stavarache M, Samuli C, Popovici CI, Tarcau D, Vantu V. 2015. The productivity and quality of alfalfa (Medicago sativa L.) in Romanian forest steppe. Notulae Botanicae Horti Agrobotanici Cluj-Napoca 43 (1): 179-185. DOI: $10.15835 /$ nbha4319939

Suwignyo B, Bela P, Nafiatul U, Ristianto U, Cahyo W. 2016. Effect of phosphate fertilizer and arbuscular mycorrhizal fungi on the nutrient content, phosphate uptake and in vitro digestibility of alfalfa. Buletin $\begin{array}{llll}\text { Peternakan } & 40 & \text { (3): } & \text { DOI-210. }\end{array}$ 10.21059/buletinpeternak.v40i3.12401

Suwignyo B, Bambang S, Cuk TN, Nafiatul U, Nilo S, Bambang WHEP. 2017. Generative plant characteristics alfalfa (Medicago sativa L.) on different levels of dolomite and lighting duration. Proceeding of the 1st International Conference on Tropical Agriculture 2017: 353-361. DOI: 10.1007/978-3-319-60363-6_34

Tiwari G, Singh R, Singha N, Choudhury DR, Paliwal R, Kumar A, Gupta V. 2016. Study of arbitrarily amplified (RAPD and ISSR) and gene targeted (SCOT and CBDP) markers for genetic diversity and population structure in kalmegh [Andrographis paniculata (Burm. f.) Nees]. Industr Crops Prod 86: 1-11. DOI: 10.1016/j.indcrop.2016.03.031

Turan N, Celen AE, Ozyazici MA. 2017. Yield and quality characteristics of some alfalfa (Medicago sativa L.) varieties grown in Eastern Turkey. Turkish J Field Crops 22 (2): 160-165. DOI: $10.17557 /$ tjfc. 356236

Widiastuti E, Evy L. 2016. Growth and biomass soybean (Glycine max L.) varieties performance in paddy field of liquid organic fertilizer application. Jurnal Ilmu Pertanian Indonesia 21 (2): 90-97. DOI: 10.18343/jipi.21.2.90.

Yari M, Reza V, Abbas AN, G R Ghorbani, P Rezvani M, A Jonker, P Yu. 2012. Botanical traits, protein and carbohydrate fractions, ruminal degradability and energy contents of alfalfa hay harvested at three stages of maturity and in the afternoon and morning. Anim Feed Sci Technol 172 (3-4): 162-170. DOI: 10.1016/j.anifeedsci.2012.01.004.

Ye YJ, Wu JY, Feng L, Ju YQ, Cai M, Cheng TR, Pan HT, Zhang QX. 2017. Heritability and gene effects for plant architecture traits of crape myrtle using major gene plus polygene inheritance analysis. Sci Hortic 225: 335-342. DOI: 10.1016/j.scienta.2017.06.065. 